\title{
Widening equity and retaining efficiency: Considerations from the IBSA southern coalface ${ }^{2 / 2}$
}

\author{
Salim Akoojee ${ }^{\mathrm{a}, *}$, Mokubung Nkomo ${ }^{\mathrm{b}}$ \\ ${ }^{a}$ University of Witwatersrand and merSETA, South Africa \\ ${ }^{\mathrm{b}}$ University of Pretoria, South Africa
}

\section{A R T I C L E I N F O}

\section{Keywords:}

South-South collaboration

Equity

Access

Social effectiveness and social efficiency

Higher education

\begin{abstract}
A B S T R A C T
Access to higher education is a key challenge of the 21st century state. The link between higher education and personal and socio-economic development has intensified the need for ensuring that greater numbers of citizens have expanded access to and have been provided with quality higher education. The article seeks to explore how initiatives for increased access to higher education are experienced in India, Brazil and South Africa. As signatories to the IBSA declaration in the spirit of South-South cooperation, the three countries have publicly declared their commitment to enhance equity by, for example, widening access to higher education. We review the way in which the three countries have implemented key equity initiatives and draw lessons from their practice. Notions of 'effectiveness' and 'efficiency' are used to understand the extent to which each of the individual systems is responsive to the equity agenda. We find that while there have been notable attempts to implement the equity agenda in the quest for making their systems more 'socially effective'. This is countervailed by a more pervasive 'efficiency' doctrine, underpinned by a market-driven economic paradigm. It is concluded that the innovative practices in each of the countries suggest important strides in the equity agenda but also that much still remains to be done. While the article represents a starting point for the much-vaunted South-South collaboration, tentative findings suggest that a more deliberately articulated policy framework characterized by greater inclusion of those previously excluded is necessary in each of the countries if significant and sustainable development is to be achieved.
\end{abstract}

(c) 2010 Elsevier Ltd. All rights reserved.

\section{Introduction}

Equity and access ${ }^{1}$ in higher education are critical for achieving both social and economic progress. As signatories to an initiative on South-South co-operation, India, Brazil and South Africa have publicly espoused their commitment to enhance equity by, for example, widening access to higher education in their respective countries. This equity perspective, defined as a desire to achieve 'social effectiveness', provides the basis for improved distribution of educational resources to less advantaged communities, which not only takes account of the wide array of available potential and student diversity, but also increases the capacity of countries to move up the social value chain (see Nkomo et al., 2007). However,

\footnotetext{
IBSA is the acronym commonly used as a reference to cooperation arrangement involving India, Brazil and South Africa.

* Corresponding author at: P.O. Box 34198, Erasmia, Pretoria, 0023, South Africa. Tel.: +27 825477951; fax: +27 123022901

E-mail address: sakoojee@merseta.org.za (S. Akoojee).

1 'Equity' is understood to mean the application of the fairness principle applied equally to all members of society. In the context of historical inequality the concept implies a commitment to compensate for the contrived disadvantage of particular groups as it seeks to achieve social justice. Access in this article refers to the inclusion of those previously excluded from entry to higher education.
}

this social effectiveness needs 'active', as opposed to 'passive', strategies for effective equity outcomes to be realised. ${ }^{2}$

The three countries which form the basis of this study have been deliberately chosen on the basis of recent proposals for South-South political, social and economic collaboration. In 2003, the Foreign Ministers of India, Brazil and South Africa committed themselves to the establishment of a Trilateral Joint Commission in what came to be called the Brasilia Declaration. ${ }^{3}$ This cooperation

\footnotetext{
${ }^{2}$ We distinguish between active and passive access strategies. The latter refers to initiatives including, admission requirements, 'meritocratic' perspectives of standards being retained while committing to diversity, as opposed to the former which is the active recruitment of traditionally excluded groups and initiatives to ensure retention by inter alia, deliberately ensuring staff diversity and inclusion by attention to education deficits present in other parts of the system (a more detailed discussion is to be found in Akoojee and Nkomo, 2007).

${ }^{3}$ The Brasilia Declaration (6th June 2003) is a landmark agreement signed between Brazil, India and South Africa. It commits the three countries to close cooperation through what has come to be called the IBSA Accord. The Foreign Ministers committed to working closely on political, social and economic issues. They agreed "...to hold regular political consultations on international agenda items. . exchange information on areas of mutual co-operation in order to coordinate their positions on issues of common interest. "For the full declaration see, http://www.dfa.gov.za/docs/2005/ibsa_brasilia.htm (accessed November 22, 2006)
} 
among countries in the southern hemisphere ${ }^{4}$ which represents a departure from the dominant North-South tradition provides an important basis for analysis.

The article reviews the current equity initiatives in the higher education systems of the three countries and draws lessons from their practice. This exploratory analysis of higher education access initiatives in India, Brazil and South Africa shows how attempts have been made to include those previously excluded. In so doing, it provides a glimpse of the lessons to be learnt as they move towards establishing the importance of South-South co-operation initiatives, and greater attention to equity in the provision of higher education to a wider proportion of the populace.

There is an inevitable tension between social effectiveness and efficiency that invariably accompanies such initiatives. In demonstrating how equity in higher education is experienced in India, Brazil and South Africa, the article offers a preliminary assessment of the possible efficacy of South-South co-operation efforts in an attempt to establish mutual learning and development.

The article begins with a brief exposition of concepts of social efficiency and effectiveness and then highlights some key caveats necessary in understanding this analysis. This is followed by an overview of equity initiatives in each of the three countries, with a concluding section that reflects on the key issues emanating from the cases.

\section{Understanding equity, efficiency and transformation in higher education}

Social effectiveness perspectives are, however, countervailed by a pervasive 'social efficiency' perspective - a perspective dominated by an outcomes discourse that places a premium on the inputs (usually resources) invested in the education system. In education, it has been appropriated to assume that efficiency is associated with doing more with less and a commitment to maximising 'return on investment'; and often interpreted within a perspective of fiscal conservatism. It has, as we will argue, become a powerful force that tends to work against the 'active', as opposed to 'passive' equity' impulses necessary in developing contexts which is often evidenced by a discourse of a retention of standards, pursuance of 'best practice' and responding to higher education that is 'world class' (see for instance Lockheed and Hanushek, 1994; Psacharopoulos, 1973, 1980). It is unquestionable that higher education policy needs to be underpinned by both goals of efficient resource allocation (social efficiency) and equitable distribution of these resources in society (equity leading to social effectiveness) (Wößmann and Schütz, 2006). Clearly, these goals should not be mutually exclusive. An effective higher education system must by its very nature use resources efficiently to maximise impact and avoid wastage, but must be equally be committed to actively encourage access amongst those traditionally excluded. Thus the view held by Wößmann and Schütz (2006) that equity is a matter of political choice, is particularly pertinent.

Wößmann and Schütz (2006) point out that part of the challenge in assessing and evaluating equity and social effectiveness is related to the "general evasiveness of clear scientific definitions of issues of fairness and justice" (p. 3). While accepting that equity in education, and higher education in particular, is largely linked to equality of opportunity (in keeping with Betts and Roemer, 2006), they point out that this suggests that educational outcomes should not depend on social constructs of race, gender or

\footnotetext{
${ }^{4}$ For background on key moments in the development of South-South cooperation see http://tcdcl.undp.org/history.aspx (accessed on 5/12/2008). Also see the Executive Board of the United Nations Development Program and of the United Nations Population Fund report (21 March 2006).
}

family background. This leads to the logical conclusion that "equity will be achieved even if there is inequality in educational outcomes" (Betts and Roemer, 2006, p. 3). This notion of equity is however glib in its treatment of equity. First, notions of equity need to be nationally debated resulting in consensus so that priorities are clearly defined, making it less nebulous. The national consensus on equity is therefore, neither difficult to construct nor is it amorphous. Second, they could underpin any evaluation mechanism, making it less challenging to evaluate. Third, educational outcomes are intrinsically linked to socio-economic factors that impact on outcomes (see for instance Betts and Roemer, 2006; Palmer et al., 2006).

Furthermore, the concept of equity needs not to be considered in passive terms; it needs to be vigorously and actively pursued to enable the achievement of identifiable outcomes. Our notion of this 'active equity' perspective suggests that a system is only truly equitable, if equity is purposefully pursued and which makes it deliberately transformative. ${ }^{5}$

\section{Salient features, caveats and the rationale}

It is necessary to signal four caveats associated with this complex analysis. Firstly, that in light of the contextual differences, it is unlikely that direct comparisons can be made, nor should they be attempted in each of the three countries located as they are in different continents, with vastly differing cultures, histories and experiences. We attempt to provide lessons from widely divergent contexts united by their discourses of equity and efficiency and joined by their need to engage in areas of mutual interest in a South-South collaboration initiative. There is clearly an implicit difficulty in attempting this objective from a comparative education perspective as Carnoy (2006) reminded delegates at the 50th anniversary of the Comparative and International Education Society (CIES):

We focus on context, on the one hand, and on the other, universal comparisons across contexts. Bringing this into the realm of practice, which is highly contextual, usually means decontextualizing our research - universalizing comparisons just when contextual comparisons should be most important (Carnoy, 2006, p. 568).

The lessons derived from the three contexts therefore need to be carefully considered in light of Carnoy's conundrum.

Second, the article represents an attempt to engage social issues in the different countries and serves as a starting point to indicate areas of relevance which serve as a basis for the cooperation agreement. In this regard, the lessons learnt need careful consideration in the context of the particular circumstances underpinning each country. The elaboration of these strategies, therefore, will enable understanding of the very different circumstances of their implementation. It is assumed that by so doing, it will enhance implementation of successful policies and practices and, where they are lacking or deficient, will provide the basis for understanding the associated complexities of implementation.

Third, the focus on equity and efficiency does not exclude considerations for quality that pervade the current higher education discourse internationally. We have contended elsewhere that the commitment to quality cannot be considered outside of the equity imperative especially in a developing context

\footnotetext{
${ }^{5}$ Transformation in this work refers to the radical overhaul of social thinking that results in meaningful social transition. In the South African context, this refers to the need to ensure that traditional exclusive systems are more inclusive and that the process of achieving identified outcomes are participatory.
} 
where social stratification requires some concerted strategies to come to grips with exclusion. ${ }^{6}$

Fourth, it is worth noting that the availability of data from each of the three countries is uneven. An earnest effort has, nevertheless, been made to identify key equity prerogatives that pertains in each of the countries studied.

\section{Country contexts - South Africa, India and Brazil}

The following section explores some of the salient higher education equity and efficiency issues in South Africa, Brazil and India.

\subsection{Equity in the South African higher education system}

In South Africa, the imperative of equity in education to spur social development is particularly pressing, especially given its generally poor skills level, low standing in international social development measures and the unusually high poverty levels (Bhorat and Kanbur, 2006; Walsh, 2007; Alcock, 2007). The Income and Expenditure survey conducted in 2005/6 reported that while $10 \%$ of the population earn more than $50 \%$ of household income, the poorest $40 \%$ of the population account for less than $7 \%$ of this, with the poorest $20 \%$ accounting for less than $1.5 \%$ (Stats SA, 2008). South Africa is also ranked amongst one of the most unequal countries in the world. Woolard and Woolard (2008) point out that in the period 2001-2005, poverty had begun to decline, ${ }^{7}$ but might be less than ideal unless urgent fundamental changes are undertaken to address the dire state of affairs.

The Gini coefficient ${ }^{8}$ for the country was placed at 0.72 (Stats SA, 2008) with significant racial disparities, ${ }^{9}$ which makes South Africa the most unequal country in the world. In the 2009 Development Indicators report, issued by the Presidency's deputy director-general, Alan Hirsch, the Gini coefficient reached 0.666 in 2008, with one report placing it as high as 0.679 (Pressly, 2009).

This situation is not helped by the unusually high unemployment rate, and evidence of a significant number of youth (aged between 18 and 24) who according Cloete (2009) number a little over 2.8 million, who are not in education, employment or training (referred to as NEETs). More importantly, while the chances of gaining employment is significantly increased once a tertiary qualification is attained, and despite the fact that there are, nevertheless, considerable demographic, institutional and programme choice considerations that hinders the prospects of some of those that qualify (see Bhorat et al., 2010), it is clear that social progress is unlikely to be achieved for many without significant advances in higher education access. The need for the country to advance the social development agenda by effective investment in education to enable broader participation is abundantly clear.

\subsubsection{Historical context of higher education deprivation}

The lack of equal education under apartheid was most notable at the higher education level (DoE, 2008). The result of this racially exclusionary practice was so pervasive as to have had considerable impact on the current pool of human resources which translated

\footnotetext{
${ }^{6}$ For an elaboration of this argument, see Nkomo (1992); our analysis in Akoojee and Nkomo (2007), and Nkomo et al. (2007).

7 Woolard and Woolard (2008, p. 78) cite the figures by van der Berg and Louw (2003), who when using datasets from the All Media and Products survey (AMPS) found that when selected indicators of poverty were used, assuming poverty line of about US\$ 450 of income per year found that reduced from 41.3 (in 2000) to 33 (in 2004).

${ }^{8} \mathrm{~A}$ value of one reflects complete inequality while a value of zero reflects complete equality. A Gini coefficient above 0.5 "is unacceptably high", according to the Human Development Report.

${ }^{9}$ Gini for Africans was estimated to be higher (at 0.63 ) than other racial categories (between 0.56 and 0.59 ).
}

into a tremendous higher education deficit for black people in general.

Since 1994, there has been considerable policy development by enacting various higher education legislation, ${ }^{10}$ designed to reverse the apartheid historical deficit. Institutions were expected to be reflective of the population demographics, under the sway of an overall policy direction of massification. ${ }^{11}$ The equity imperative to transform the higher education landscape took various forms since 1994. In the context where the user-cost of higher education is quite significant ${ }^{12}$ and the entry requirement quite stringent, ${ }^{13}$ implementing access appeared to be ad hoc and institutions were broadly left to themselves to identify the mechanics of achieving targets considered appropriate. National policy in the form of financial aid through the National Student Financial Aid Scheme (NSFAS) and concerted institutional support programmes, referred to as academic development, for the envisaged newly-admitted cohort of black students formed the basis of redress initiatives.

Redress initially took the form of 'access as participation', a focus on increasing the numbers of black students (i.e. those formerly excluded). When the results of this policy thrust resulted in increased failure rates, it was replaced with the notion of 'access with success', ${ }^{14}$ an approach that suggests that it was perhaps more important that the outcomes of greater participation are given attention. However, each of these imperatives have been given equal attention in policy perspectives, with a funding incentive (the national student funding scheme) and some attention to academic development initiatives representing the latter. Each of these initiatives is discussed in the next section.

4.1.1.1. National student funding. The National Student Financial Aid Scheme (NSFAS) launched in a 1996 promulgated by the then President Mandela is primarily a loan scheme, part of which can convert to a bursary on evidence of satisfactory performance. ${ }^{15}$ As a means to enable those who were previously disadvantaged from accessing higher education, the NSFAS had provided funding to 659000 students at a cost of $\mathrm{R} 12$ billion ${ }^{16}$ since inception over a decade ago. With only $1 \%$ obtained from the private sector, the fund is almost exclusively dependent on government. The review of the fund by a Ministerial Committee found that the biggest impediment to success was funding:

The Committee found that NSFAS's major shortcoming is that funding falls far short of demand. Current estimates are that NSFAS has less than half of the funds it needs to meet the demand for financial aid from qualifying applicants, even at current participation rates. (DHET, 2010, p. xiii)

\footnotetext{
10 See, for instance, the following policy documents: RSA (1996, 1997a,b, 2001). 11 This notion was discussed extensively in the 1996 National Commission on Higher Education Plan.

${ }^{12}$ It costs in the region of between R 15,000 to R 20,000 (US2500\$-US 3000\$) per annum for fees alone, excluding costs of learning materials, accommodation and transport. These fees are quite steep given the high incidence of poverty in the country.

${ }^{13}$ For instance, according to Perry and Arends (2003), on average, there have been a steadily increasing number of candidates who have enrolled for the Senior Certificate Examination (incorporating those that have qualified for university entrance), particularly between 1999 and 2001 - 48.8\% (1999) to 61.7\% (2001). University passes had increased from an annual 63715 learners to 67 707, with inevitable implications for university access, where total enrolment in the university system is 630000 and participation rates are on average $16 \%$ (in 2002 ) (p. 318). It should be noted that the 12th grade pass rate in 2006 has declined. ${ }^{14}$ See Akoojee and Nkomo (2007).

15 President Mandela at the launch on of the National Student Financial Aid Scheme, Pretoria, 27 June 1996.

16 About US\$1.6 billion at current exchange rates of R7.5 to a US\$.
} 
Some attempt have been made in the past to subvent the fund from private sources, but this has had limited success, with for instance a mere $28 \%$ been raised through non-state sources in $2004 .{ }^{17}$ Since up to $40 \%$ of the disbursement can be provided as a bursary for satisfactory performance (passing of all courses taken), the fund is reportedly continuously in need of additional capital. As an access mechanism targeted at providing opportunities for those who would otherwise be unable to access benefits of higher education, the system succeeds in enabling more students to access higher education. Importantly, since the funding is provided to institutions, they find themselves having to reduce the amount that students can be subsidised, sometimes this is even less than that required for basic tuition costs (DoE, 2008, p. 65). The mechanism is, therefore, considered inadequate for enabling access.

4.1.1.2. Academic development. The Academic Development Program (ADP) as an (essentially internal) institutional academic redress strategy has been used over several years. The National Plan for Higher Education (NPHE) (RSA, 2001) made the point that the "... role of academic development in improving the efficiency of the higher education system in terms of graduate output is critical" (RSA, 2001, p. 31). The current form of ADP favoured in the NPHE includes the following key features: 'extended curricula' rather than 'supplementary support'; the need for historically disadvantaged students to be integrated into the mainstream; the need to be responsive to all students rather than only those who would not normally be admitted (i.e. it should not be directed at black students only); and ensuring that 'technology driven' approaches are not the preferred modus operandi to deal with disadvantage. It has nevertheless been argued that, “...debates about what it means to provide 'epistemological access' in terms of curricula and teaching methodologies have been sidelined in favour of the need to develop curricula which will allow students to become members of a global workforce" (Boughey, 2003). The sidelining of academic development provision, has, however, been unsurprising since academic development has essentially been undertaken as a marginal process outside of institutional transformational initiatives. Thus criteria for Academic Development funding stipulations which included inter alia, the need for programmes to be 'accredited' and the time taken to be extended by a minimum of six months, in order to qualify for official funding.

More recent proposals which draw from Walker and Badsha (1993), what later came to be known as the 'infusion model', see academic development as central to transformation. Boughey (2007), for instance, calls for a 'Third Generation Academic Development' which is likely to replace the dominant 'policing' dimension of quality assurance, once these are rendered less appropriate. The more transformative dimension of Academic Development, draws from the HEQC Founding document (CHE, 2001), understood as both transformation of individual learners through the development of personal capacity and in the sense of contributing to social development and growth at a wider societal level. This is likely to take place especially since many academic development personnel were absorbed into quality audit units.

The endearing issue of institutional transformation is, nevertheless, still evident as the latest Ministerial Committee Report makes clear, “. .. the academic development and support strategies introduced by institutions to assist black students to bridge the gap between school and university are not likely to succeed unless, and until the institutional culture in which they are embedded is changed and transformed" (DoE, 2008, p. 66).

\footnotetext{
17 http://www.nsfas.org.za/nsfas/jsp/donor_main.jsp (accessed on October 29,
} 2004).

\subsubsection{Summary of the South African case}

The South African case shows an attempt to balance issues of equity and efficiency. The imperative to increase access through massification in the post-apartheid era has been replaced with a much more cautious approach in the form of planned growth. This reinforces the view, either real or imagined, that access is not as serious as it ought to be. Some measures have also been instituted for those unable to afford the costs of higher education opportunities by access to funding. However, much still needs to be done in order to overcome the constraints.

\subsection{Equity in the Brazilian higher education system}

Income inequality in Brazil ${ }^{18}$ (Ferreira and Barros, 2000), as in South Africa, is manifested in the education system and takes on racial, social class and spatial characteristics. Education exclusion represents a crucial cause, and manifestation, of poverty, which in turn is considered the main reason behind exclusion (World Bank, 2003: para. vii). Interestingly, the inequity is such that two-thirds of students attending the largely free public higher education institutions come from the upper income quintile, while only 5\% come from the bottom two quintiles combined (World Bank, 2003).

Importantly, the public higher education system in Brazil collectively enrols between $20 \%$ and $35 \%$ of all students. This situation has prompted the suggestion that "... Brazilians have learnt some ways of developing and maintaining a small number of good quality, elite institutions, but do not know how to attend to the needs of the majority" (Schwartzman, 1995). There has, nevertheless, been a notable higher education expansion since this development. Over the past decade, public education has seen a doubling of enrolment from a little over half a million enrolments (578 625) in 1990 to almost a million (939 225) by $2001 .{ }^{19}$

Private higher education in Brazil absorbs more than $70 \%$ of the enrolments in higher education and comprises far in excess of three fifths (88.1\%) of all institutions in the sector. This 'mass private sector' (Geiger, 1986) has been viewed as an alternative to a 'costly and inefficient' system and has largely been responsible for the doubling of enrolment since 1995 from under a million enrolments (962 000) to slightly over 2 million (2 092000 ) in 2001 (INEP, 2004, quoted in McCowan, 2007). It has been caustically noted that students either get accepted at public institutions, “... or go to private institutions, where the courses are also of low prestige and quality, for which they have to pay". ${ }^{20}$ Claims of serious quality deficits ${ }^{21}$ have given rise to some quite drastic measures to ensure its regulation.

Clearly then, the inequities in the Brazilian higher education system have been widely documented and:

For different reasons, therefore, access is limited to the higher socio-economic groups in both the public and private sectors. On top of this, there are racial inequities, with low representation of African Brazilians and indigenous peoples (McCowan, 2007, p. 585).

The mechanisms to engage this inequity include enhanced schooling opportunities, more liberal admission criteria and some quite novel individual student targeting by some public education institutions, while a loan system has provided some access to the large private sector.

\footnotetext{
${ }^{18}$ It has been estimated, for instance, that $50 \%$ of income is earned by $10 \%$ of the population. It is worth noting also that Brazil and South Africa have the highest Gini coefficients in the world.

19 Reasons for this expansion include the increase in primary and secondary enrolments and some quite radical increases in investment into the sector. More details and discussion of these features are to be found in Batista (2003).

${ }^{20}$ Schwartzman (1995). op. cit. p12/3.

21 See Schwartzman (1995) and Durham (2003).
} 


\subsubsection{Transforming schooling and targeting}

One of the most critical constraints to higher education access in the Brazilian case is related to what Durham (2003) calls "structural obstacles". This is associated with limited basic schooling access ${ }^{22}$ and limited numbers leaving secondary education which has placed the spotlight on schooling as a mechanism to engage the access imperative. The fundescola program $^{23}$ was designed to increase access to primary and secondary education through local involvement at school level. This initiative promised to vastly improve the quality of education by tailoring schools to the needs of communities (Winkler and Gershberg, 2000). Although the success of this intervention has, however, still to be evaluated, the focus on schooling clearly expands the ambit for higher education access, by exploring expanding opportunities outside of the university system.

The targeting of particular candidates at school level by some of the more prestigious universities is a useful means by which to enhance opportunities for those that have the potential, but are unlikely to get the opportunity to access university study. In this regard, the National University of Brasilia (UNB) monitored topperforming students beginning in Grade 9 through their graduation. Some public universities allocate up to a quarter of their new enrolment for such students. Whilst these measures have been met with significant opposition by more affluent sectors of Brazilian society (World Bank, 2003), the initiative is, nevertheless, notable for its attempt to retain the overall size of the education system, while enabling inclusion of more historically under-represented groups.

\subsubsection{University quotas}

The implementation of quotas represents a recent development in an attempt to widen access to public higher education. It flowed from isolated practice in some universities. ${ }^{24} \mathrm{~A}$ proposal promulgated in April 2004 obliges public universities to reserve half their places for students from public schools, with some places reserved exclusively for Afro Brazilian students, depending on the proportional population data for that region (Brasil, 2004). There are concerns about the racial, rather than the socio-economic basis for reservation, but its utility as a short-term measure for redress is justified while a more sustained longer term strategy is being devised.

\subsubsection{Relaxing tight admission}

A pre-university examination, referred to as the vestibular system, has long been considered an important mechanism for higher education exclusion. According to McCowan (2007), “. . . it is very hard to enter a public university and receive a free higher education without having previously been to a private school and attended a private pre-vestibular course" (p. 585).

In an attempt to eliminate the inequality produced by the vestibular system, the Ministry of Education has developed an alternative 'National School Voluntary Examination (ENEM)'. ${ }^{25}$ In

\footnotetext{
22 Only in 2000 did school attendance reach $97 \%$.

${ }^{23}$ A World Bank program designed to improve schooling outcomes, especially for poor children in Brazil.

24 The State University of Rio de Janeiro was the first to adopt the policy, setting aside a $40 \%$ enrolment quota for the AfroBrazilians, and a further $10 \%$ for other students from public schools.

${ }^{25}$ ENEM is a non-mandatory Brazilian national exam. While primarily designed to evaluate school quality, it is used widely by private universities, and by the more renowned public universities, to supplement existing criteria. Thus the University of São Paulo and Faculdade Cásper Líbero may use the score of the candidate as a way of providing extra points on the final score, depending on the student's performance. However, it has been reported that from 2009 on, most federa universities in Brazil will use the ENEM as part of their admission exam, either as the whole test itself, or as a first level of the exam, or even just as a way of selecting remaining candidates (http://en.wikipedia.org/wiki/Enem_(exam) downloaded 26.03.2010)
}

addition, the yearly examinations at public secondary schools have been touted as having a role in assisting students to prepare for this national admission examination. While the move represents a serious attempt to move away from what has been hitherto considered the 'gold standard' of the higher education selection process, its hold as an 'objective first choice' admission requirement is clearly hard to break.

\subsubsection{PROUNI: University for all}

Referred to by the Minister of Education, Tarso Genro, as the 'nationalization' of private university places, the Programa Universidade para Todos (University for All Programme), or Prouni as it has become known, is an initiative to expand higher education opportunities to under-represented groups. Implemented in September 2004, Prouni was designed to use tax exemptions to provide unfilled places in private institutions free of charge to lowincome students in return for tax exemptions. While state or nonprofit institutions could dedicate up to $20 \%$ of their places for reimbursement, profit-making institutions were able to allocate $10 \%$ of their places for this purpose. The access of non-traditional groups is achieved by ensuring that the places that qualify for reimbursement go to students from families whose per capita income is not more than 1.5 times the minimum wage. A total of 107,136 new places have been awarded in its year of inception (Brasil, 2004; quoted in McCowan, 2007).

In addition, a loan system was introduced as a response to increasing access (and thereby efficiency) within the private system ${ }^{26}$ specifically. A loan of up to $70 \%$ of the fee was paid directly to the institution at minimal interest payable after graduation and provides an important avenue to those unable to afford access. It has been reported that more than 277000 students benefited from the programme since inception (Folha de São Paulo, 2004 quoted in McCowan, 2007, p. 587).

\subsubsection{Summary of the Brazilian case}

Brazilian higher education is noted for its quite rapid expansion over the recent past. This development is important from a national skills development perspective. More creative attempts have been made to deal with widening the public education system to become more inclusive. The existence of a vibrant private sector, while it has the effect of enhancing access, has negative equity impacts. Clearly, current attempts to provide incentives to the private sector have not been able to respond significantly to the access debate, it does provide an important starting point for expanding enrolment for those less privileged.

\subsection{Equity in the Indian higher education system}

Three areas serve as structural impediments to higher education access in India: caste, poverty and gender. While these categories are not mutually exclusive, they need to be understood as distinct areas which restrict higher education access in the Indian context.

Caste is described by Chitnis as an "... ancient and powerful tradition of exclusion (which)... goes back to the 8th century when the Brahman universities considered women and some specified 'underclasses' as being unfit for learning” (Chitnis, 2000, p. 10). With distinct poverty and gender dimensions, the challenge of caste becomes particularly acute and undermines various reform initiatives. Gender exclusion in itself is also especially acute in a country where stereotyping is endemic, resulting in girls having experienced higher school dropout rates than boys (Jeejeebhoy, 1993; Colletta and Perkins, 1995).

\footnotetext{
${ }^{26}$ This program called FIES, Programa de Financiamento Estudantil, was initiated in
} 1999 and replaced a previous scheme known as Creduc 
As the second largest higher education system in the world, India currently has 322 university-level institutions and more than 14000 colleges catering for eight million direct and full-time students. The system is vastly heterogeneous with some institutions existing as 'university affiliated colleges' and others as special professional institutions for training in fields such as medicine and agriculture, and yet others as special research institutes.

The system has undergone considerable expansion since independence. In a mere forty years the number of universities expanded sixfold, the number of students by 22 times and college teachers by a little more than ten times (Chitnis, 1993). Enrolments, for instance, increased from 0.4 million in 1950 to 6.4 million in 1995/96 (Indiresan, 2000) and provides the context for a vastly expanded system.

Access to education in general and higher education in particular has been a burning issue in India since independence. The impulses of affirmation and excellence have dominated the higher education discourse during the post-independence period.

\subsubsection{Quotas}

At independence, the political leaders, largely prompted by public expectations resulting from the promises of the independence movement for a better life, chose to deliberately respond to those groups that had been denied full participation in society and were disadvantaged from centuries of neglect. Special constitutional provisions, called 'reservation', were enacted for what were called 'backward classes' referred to as 'scheduled castes' and 'scheduled tribes'. In order to engage their participation in the economic and political life of India, positions were reserved in the civil service (Chauhan, 2004).

The higher education component of this development was the establishment of quotas for designated student places. At some universities, as high as one-fifth of the total complement were affirmation enrolees. Grant allocations were also provided to enable participation of 'disadvantaged' students so that an adequate cohort could take their place in positions reserved for them.

There have been some concerns that the policy has benefited only a select few, but the results have shown that there has, nevertheless, been a marked shift to more representation from previously disadvantaged lower castes, members of minority religions and certain groups, for example, Muslim minorities and women (Chauhan, 2004). ${ }^{27}$

The policy of affirmation has not gone unchallenged. Besides those vocal protests of those who for meritocratic reasons see the policy as unfair, there are also those who suggest that the policy rewards those who are already advantaged. The countrywide protests of May, 2006, for instance, are sparked off when the proposal to increase reservations by $27 \%$ for 'Other Backward Classes' (OBCs) $)^{28}$ was mooted.

\subsubsection{Expansion}

The Indian higher education system has also been subject to considerable growth, a process considered to be the result of

\footnotetext{
${ }^{27}$ For at least one institution, the change resulted from a more than two-thirds representation by forward classes in the $1988 / 9$ year to a situation wherein the majorities were underclasses in a period of six years. In addition, some quite startling results of access for women have been achieved in the period 1982-1994. The number of colleges exclusively for women, for instance, increased from 647 to 1070 .

${ }^{28}$ See for instance relevant articles in the popular press: In Khaleeji Times "Doctors block roads in India caste quota protests" dated 17 May 2006 (Reuters), available at http://www.khaleejtimes.com/DisplayArticleNew.asp?xfile=data/subcontinent/ 2006/May/subcontinent_May610.xml\&section=subcontinent; and; In the Times of India, “OBCs join protest, don't want more quotas", printed, Monday, May $\overline{15,2006}$ Times News Network, available at http://timesofindia.indiatimes.com/articleshow/ msid-1533629,curpg-2.cms.
}

expansion. The steady rise in commerce enrolment (from 14 to 20\%); falling natural science enrolment (30-20\%) and almost fixed humanities and social sciences enrolment (at 40\%) has often been used as evidence for a less than effective massification (Grant, 1994) imperative. Some commentators have suggested that the government deliberately instituted an aggressive program to expand lower cost subject areas and has attempted to divert students into these disciplines (Chitnis, 2000, p. 10). This situation, together with the somewhat stunted funding regime, provides the rationale for the view that "the expansion is obviously unwieldy and should have been curbed" (Chitnis, 1993, p. 494). In recent times, only $17 \%$ of Indian students are enrolled in professional courses such as engineering and medicine while the remaining students were pursuing degrees in the sciences, the humanities, and commerce - the latter which includes business and economics, is not considered a professional field (Neelakantan, 2005).

Despite the relative affordability of higher education, funding has not kept pace with expansion. This might explain the quality defects in the system which is attempting to expand without complementary resources. Since government pays for almost $90 \%$ of the cost of higher education in India (Chitnis, 2000), there have been calls for some serious review of financing of the HE system; with some cost-sharing proposals (see for instance Tilak, 1993).

\subsubsection{Summary of the Indian case}

The Indian case reflects a considerable expansion thrust, with some degree of specialisation into specialist, nich3 markets, which necessarily exclude on the basis of academic performance. The attention to various redress mechanisms has, nevertheless, meant that an earnest attempt is made to include as many traditionally disadvantaged students as possible. However, in the context of considerable expansion, the impact of an open door policy might well be counter-intuitive, in the context of uniform funding mechanisms. Use of quotas, however, might help those traditionally excluded from the race, but might not enable success. Thus the need to balance both the supply and demand imperatives for ensuring that those traditionally excluded obtain meaningful opportunities to access employment opportunities. This case suggests that inclusion still has some way to go before it is able to effectively address considerations for institutional redress.

\section{Some comparative reflections}

Equity in education is clearly viewed as the key to social progress and is high on the list of priorities in the three countries. The key operative concepts are 'transformation' for South Africa, 'targeting' for Brazil, and 'affirmation' for India. There is a general recognition among the three countries that if their developmental goals are to be fully achieved, a collective effort is necessary. Their agreement is ostensibly motivated by a desire not only to uplift the welfare of their citizenry, but to render them competitive in the global economy as well. The global economy, however, imposes its own logic through the premium placed on efficiency that often serves as a counterweight to the social imperative of equity. The logic permeates the operation of their political economies and compromises and bedevils policy intentions. It deserves noting also that there are relatively powerful constituencies, mainly the privileged classes, who are strong proponents of the efficiency discourse and opposed to equity initiatives. Such opposition has legislative, policy and implementation implications in that it often attenuates effective enforcement.

\subsection{Motivation for higher education access}

Developments in Brazilian higher education come from a variety of sources including a community-level push for redress of 
past restrictions. While an increasing demand for high skill workers facilitates this push, it does not appear to be as powerful a force, as it is in India and South Africa. In India the equity impulse has its roots in the pre-independence movement and in recent years driven in part by the high-skills demand of the global economy. Similarly in South Africa the imperative to ensure increasing equity and access to higher education opportunities dates back to the equality aspirations during the colonial and apartheid eras and propelled in recent years by a strong desire to address the critical skills-shortage crisis and a desire to be competitive in the global economy. The quest for effective participation in the global economy with its strong market orientation requires compliance with the efficiency logic. An inevitable tension is thus created between the two imperatives, namely equity and efficiency, with profound social consequences.

\subsection{Institutional transformation}

The need to transform institutions to accommodate a diverse student body is an urgent priority in all three countries and is demonstrated by substantial enrolments in both public and private higher education institutions. At school level there are a variety of measures in place intended to increase access using national examinations (whether of a national kind as in South Africa and India) or special targeting of disadvantaged groups. In all three countries quality, funding and the efficient allocation of resources have been at the core of their varied social democratic identities. However, success varies according to a complex of historical, political, economic, social, and local as well as global factors.

\subsection{Financial imperatives}

It bears noting that there is currently a robust debate about free higher education especially in South Africa and state budget allocation to education is by world standards quite high; in Brazil free education is available and there have been steady increases in the education budget in the recent past; and in India $90 \%$ of the higher education comes from the government and various financial measures to increase the participation rates of under privileged classes are in place. There is wisdom in instituting a system for targeting funding to needy students in cases where higher education is not free. The increasing fees charged by institutions, as a result of the dwindling state subsidy driven by strong efficiency considerations, have recently resulted in conflict at the level of the institution expressed either through student protests or administrative and academic staff complaints about management salaries that are far too high in comparison to the rest of the university employees. The financial aid system in South Africa, which features as a part-bursary provision for successful students, is unable to meet the rapidly increasing costs of university education. In India, the limited quota systems and scholarships for students from under-represented groups sometimes accommodate under-represented groups, but the general trend has been towards inclusion through the provision of a wide variety of institutional types and programs that seemingly accommodate a vast range of student needs. In Brazil, it appears that the explosion in private higher education has become a proxy for robust state subsidy although this development appears not to be sufficient to effectively address equity issues.

\section{Conclusion}

We take note of Carnoy's (2006) conundrum regarding the complexity of effecting "universal comparisons across contexts" and so our reflections are tinged with caution. It seems clear the three countries, to varying degrees and configurations, are committed to social effectiveness as well as social efficiency as fundamental requirements to achieve social progress like their developed counterparts. Their collective desire to implement educational policies that take cognizance of the balance between the two competing drives is defined on the one side by domestic exigencies (e.g., time, space, history, the balance of political and economic interests) and on the other by global imperatives (e.g., the ubiquity and primacy of the market logic). Success or failure to implement depends on their relative capacities; and it cannot be expected that they will necessarily achieve the same results, let alone parity in the balance of the two competing imperatives. What is important is their desire to collaborate to the extent possible in order to achieve the desired upliftment of their citizenry.

The consideration for ensuring that countries give serious attention to equity, social justice and efficiency imperatives enshrined in the Brasilia Declaration have been highlighted. It is evident that Brazil, India and South Africa are engaging the equity and efficiency imperatives in varied ways consonant with their contextual realities. While higher education access is an important element of the overall development trajectory in the three countries, it must also be linked to strict socially efficient requirements related to accountability.

The South-South co-operation exemplified by IBSA represents an important initiative in attempting to improve their standing as measured by the Human Development Index measures such as: healthy life spans, expansion of the knowledge base, and the attainment of a higher standard of living for significant numbers of their citizenry through cooperation. The regular IBSA consultative meetings serve as forums for generating collaborative initiatives and discussing policy and implementation strategies in areas of common interest.

There is a role that the research community, especially those involved in education, can play in the realisation of South-South co-operation goals by, to borrow Carnoy's formulation, bringing the decisions and/or resolutions from the deliberations "into the realm of practice, which is highly contextual" through decontexualising our research" (Carnoy, 2006: 568). This suggests a vigorous encouragement of research activity that can engage critical issues around the needs of the three countries and their common interests. Collaborative deliberations result in broad frameworks that serve to guide policies and programs that, with appropriate adaptation and innovation, can stimulate further advances in policy and practice literacy.

A working and sustained relationship of these three important southern hemisphere power can greatly enhance the chances of successful human development. But it will require accelerated, unrelenting and sustained commitment to break the glass ceiling to the first rank category in the Human Development Index, and to ensure a better life for all.

\section{References}

Akoojee, S., Nkomo, M., 2007. Access and quality in South African higher education: the twin challenges of transformation. South African Journal of Higher Education 21 (3), 385-399.

Alcock, P., 2007. How can we understand poverty and social exclusion and how might we combat them, some ideas for research and policy. Paper presented at the Human Sciences Research Council, Pretoria (16th October).

Batista Araújo e Oliviera, J., 2003. Expansion and inequality in Brazil. Oxford Studies in Comparative Education 13 (2), 41-68.

Betts, J.R., Roemer, J.E., 2006. Equalizing opportunity for racial and socio-economic groups in the United States through educational finance reform. In: Peterson, P.E., Wößmann, L. (Eds.), Schools and the Equal Opportunity Problem. MIT Press, Cambridge, MA.

Bhorat, H., Kanbur, R. (Eds.), 2006. Poverty and Policy in Post-apartheid South Africa. HSRC Press, Cape Town.

Bhorat, H., Mayet, A., Visser, M., 2010. Student graduation, labour market destinations and employment earnings. In: Student Retention and Graduation Desti- 
nations: Higher Education and Labour Market Access and Success, Human Sciences Research Council, Cape Town, pp. 97-123.

Boughey, C., 2003. From equity to efficiency: access to higher education in South Africa. Arts and Humanities in Higher Education 2 (1), 65-71.

Boughey, C., 2007. Marrying equity and efficiency: the need for Third Generation1 Academic Development. Perspectives in Education 25 (September (3)).

Brasil, Federal Government, 2004. Projeto de Lei - Sistema Especial de Reserva de Vagas. Subchefia de Assuntos Parlementares, Rio de Janeiro. 28 April.

Carnoy, M., 2006. Rethinking the comparative-and the international. Comparative Education Review 5 (4), 551-570.

Chauhan, C.P.S., 2004. Modern Indian Education: Policies, Progress and Problems. Kanishka, New Delhi.

Chitnis, S., 1993. Gearing a colonial system of education to take independent India towards development. In: Altbach, P., Chitnis, S. (Eds.), Higher Education Reform in India-Experience and Perspectives. Sage, New Delhi.

Chitnis, S., 2000. The challenge of access in Indian Higher Education. Liberal Education. Downloaded from http://proquest.umi.com/pqdweb?did= $65670687 \&$ sid $=1 \&$ Fmt $=3 \&$ clientId $=62906 \&$ RQT $=309 \&$ VName $=P Q D$.

Cloete, N. (Ed.), 2009. Responding to the Educational Needs of Post-school YouthDetermining the Scope of the Problem and Developing a Capacity-Building Model. CHET, Cape Town.

Council on Higher Education (CHE), 2001. Higher Education Quality Committee Founding Document. CHE, Pretoria.

Colletta, N., Perkins, G., 1995. Participation in Education. World Bank Environment Department, Washington, DC.

Department of Education (DoE), 2008. Report of the Ministerial Committee on Transformation and Social Cohesion and the Elimination of Discrimination in Public Higher Education Institutions. DoE, Pretoria.

Department of Higher Education and Training (DHET), 2010. Report of the Ministerial Committee on the Review of the National Student Financial Aid Scheme, Government Printer, Pretoria.

Durham, E., 2003. Higher education in Brazil: public and private. Oxford Studies in Comparative Education 13 (2), 147-179.

Ferreira, F., Barros, R., 2000. Education and income distribution in urban Brazil, 1976-1996. CEPAL Review 71, 41-61.

Folha de São Paulo, 2004. Ministério Público consegue liminar para retirar fiador doFies. Folha de São Paulo, 3 August 2004.

Geiger, R., 1986. Private Sectors in Higher Education: Structure, Function and Change in Eight Countries. University of Michigan Press, Ann Arbor.

Grant, H., 1994. Student selection and admission to higher education. Higher Education 27 (3), 313-339.

Indiresan, J., 2000. The dynamics of diversity and higher education: Initiatives and challenges in the Indian context. In: Beckham, E. (Ed.), Diversity, Democracy, and Higher Education-A View from Three Nations. Association of American Colleges and Universities, Washington, DC.

Jeejeebhoy, S., 1993. Family Size: Outcomes for Children and Gender Disparities. Economic and Political Weekly 28.

Lockheed, M.E., Hanushek, E., 1994. Concepts of educational efficiency and effectiveness. In: Human Resources Development and Operations Policy Working Paper Series, March 1994.

McCowan, T., 2007. Expansion without equity: an analysis of current policy on access to higher education in Brazil. Higher Education 53, 579-598.

Neelakantan, S., 2005. India's universities are falling behind their peers around the world. Chronicle of Higher Education 52 (2).

Nkomo, M., 1992. Democratizing higher education: Imperatives of quality and equality in higher education. In: Proceedings of the Eighth Biennial Congress of the South African Association for Research and Development in Higher Education, Bloemfontein, University of the Free State.

Nkomo, M., Akoojee, S., Motlhanke, S., 2007. Between a rock and a hard place: understanding the balance between access and efficiency in South African higher education. Journal of Asian and African Studies 42 (5), 399-413.

Palmer, R., Wedgwood, R., Hayman, R, King, K., Thin, N., 2006. Education out of Poverty? A synthesis report on Ghana, India, Kenya, Rwanda, Tanzania and South Africa, Centre of African Studies, University of Edinburgh, September.

Perry, H., Arends, F. 2003. Public schooling. In: Human Sciences Research Council (Eds.), Human Resources Development Review. Education, Employment and Skills in South Africa, HSRC Press and Michigan State University Press, Cape Town and East Lansing.

Pressly, D., 2009. South Africa has widest gap between rich and poor: Study finds SA now falls below Brazil, September 28, 2009.

Psacharopoulos, G., 1973. Returns to Education: An International Comparison. Elsevier-Jossey-Bass, Amsterdam.

Psacharopoulos, G. 1980. Returns to Education: An Updated International Comparison. In: King, T. (Ed.), Education and Income, World Bank Staff Working Paper No.402, Washington: World Bank.

RSA (Republic of South Africa.), 1996a. Green Paper on Higher Education Transformation. Government Printers, Pretoria.

RSA, 1996b. An overview of a new policy framework for higher education transformation. A National Commission on Higher Education Report. Government Printers, Pretoria.

RSA, 1997a. Education White Paper 3: A Programme for the Transformation of Higher Education. Government Printers, Pretoria.

RSA, 1997b. Higher Education Act 101 of 1997. Government Printers, Pretoria.

RSA, 2001. National Plan for Higher Education. Government Printers, Pretoria.

Schwartzman, S. 1995. Issues on Brazilian Higher Education and Scientific Research. A Presentation at Harvard University, School of Education. Downloaded from http://www.schwartzman.org.br/simon/harvard.htm.

Stats SA (Statistics South Africa), 2008. Income and Expenditure of Households 2005/6. Statistics South Africa, Pretoria. Downloaded from http://statssa.org.za.

Tilak, J., 1993. Financing Higher Education in India. In: Altbach, P., Chitnis, S. (Eds.), Higher Education Reform in India-Experience and Perspectives. Sage, New Delhi.

van der Berg, S., Louw, M., 2003. Changing patterns of SA income distribution: towards time series estimates of distribution and poverty. Paper delivered to the Conference of the Economic Society of South Africa, Stellenbosch.

Walker, M., Badsha, N., 1993. Academic development: the 1990s. South African Journal of Higher Education 7 (1), 59-62.

Walsh, S., 2007. Uncomfortable collaborations: Contesting constructions of the poor in South Africa. Paper presented at the SANPAD Poverty Challenge Conference, Durban, 27th June.

Winkler, D., Gershberg, A., 2000. Education decentralization in Latin America: the effects on the quality of schooling. World Bank Paper Series Paper No. 21494 World Bank, Washington, DC.

Woolard, I., Woolard, C., 2008. The social and human development context. In: Kraak, A., Press, K. (Eds.), Human Resources Development Review 2008: Education, Science and Skills Development. HSRC Press, Cape Town.

World Bank, 2003. Next Steps for Education in Four Selected States in Brazil. World Bank Report, No. 24343. World Bank, Washington, DC.

Wößmann, L., Schütz, G., 2006. Efficiency and Equity in European Education and Training Systems. Analytical Report for the European Commission, prepared by the European Expert Network on Economics of Education (EENEE) to accompany the Communication and Staff Working Paper by the European Commission. 